УДК 342.9:347.961

DOI https: / / doi.org/10.32837 / yuv.v0i6.2072

\author{
A. Кудін, \\ Науково-дослідного інституту публічного права
}

\title{
ЗМІСТ ЕЛЕКТРОННОГО УРЯДУВАННЯ У СФЕРІ АДМІНІСТРАТИВНО-ПРАВОВОГО ЗАБЕЗПЕЧЕННЯ ПАТЕНТНОЇ ДІЯЛЬНОСТІ В УКРАЇНІ
} Актуальність теми. Основними
характеристиками інформаційного
суспільства є створення глобального
інформаційного простору, що забез-
печує ефективну інформаційну вза-
ємодію людей, іх доступ до світових
інформаційних ресурсів і задоволення
іхніх потреб щодо інформаційних про-
дуктів і послуг. Знання та інформація
стають стратегічним ресурсом інфор-
маційного суспільства й провідною
галуззю економіки [1, с. 3].

Перетворення інформації на найважливіший виробничий ресурс змінює парадигму еволюції суспільства: основу розвитку інформаційного суспільства складають не традиційні матеріальні, а інформаційні, інтелектуальні ресурси, такі як знання, наука, організація, здібності людей, їхня ініціатива, формування структур і механізмів якісно нового соціального інтелекту, які відкривають кожному співтовариству нові можливості для самоідентифікації [3, с. 108].

Нині в суспільстві стрімко зростає роль технологічних інновацій, передусім сектору е-комунікацій, який отримує все більший вплив на розвиток сучасної економічної системи, адже $€$ з'єднувальною ланкою як промислової сфери, сфери послуг і споживачів, так і різних регіонів країни та економічних центрів, тому розвиток е-комунікацій як основної складової частини інформаційного суспільства для забезпечення ефективної взаємодії всіх структур суспільства, зокрема державних, $€$ актуальним завданням соціально-економічного зростання [1, с. 3].

Отже, для розбудови інформаційного суспільства в Україні варто більш системно вивчити можливості електронного урядування в окремих секторах правового регулювання, зокрема у сфері адміністративноправового забезпечення патентної діяльності в Україні.

Огляд останніх досліджень. Проблемні питання патентної діяльності крізь призму адміністративного права досліджували такі вчені, як Г. Андрощук, В. Бурячок, Є. Валькова, M. Галянтич, С. Головань, I. Запорожець, С. Золота, I. Каплун, О. Коротун, I. Кравченко, К. Куркова, А. Пишна, В. Понікаров, Г. Римарчук, О. Світличний, Д. Смерницький, О. Тандир, Є. Юркова. При цьому комплексних досліджень патентування як об'єкта адміністративного регулювання в Україні, на жаль, замало, що комплексно обгрунтовує актуальність вибраної теми статті.

Мета статті полягає в тому, щоб на основі системного аналізу норм законодавства, позицій учених-адміністративістів та науковців інтелектуального права, статистичної діяльності суб'єктів публічної адміністрації патентної діяльності сформувати зміст електронного урядування у сфері адміністративно-правового забезпечення патентної діяльності в Україні.

Виклад основних положень. Відповідно до Указу Президента 
України «Про Стратегію сталого розвитку «Україна - 2020»» від 12 січня 2015 р. № 5, Розпорядження Кабінету Міністрів України «Про затвердження середньострокового плану пріоритетних дій Уряду до 2020 року та плану пріоритетних дій Уряду на 2017 рік» від 3 квітня 2017 р. № 275, розвиток електронного урядування $€$ одним із першочергових пріоритетів реформування системи державного управління. Також у рамках реалізації Угоди про асоціацію між Україною, з однієї сторони, та Європейським Союзом, Європейським співтовариством 3 атомної енергії та їхніми державами-членами, з іншої сторони, Україна має забезпечити комплексний розвиток електронного урядування відповідно до європейських вимог [6].

Метою інновацій у сучасному інформаційному суспільстві $€$ пошук нових ефективних та справедливих способів менеджменту ресурсів знань. Відповідно до цієї мети, програма розвитку Всесвітньої організації 3 інтелектуальної власності містить пункт обміну досвідом щодо відкритих спільних проєктів у сфері інтелектуальної власності, на цій основі плануються реформування та інтеграція системи міжнародної патентної класифікації для забезпечення більш вільного доступу до технологічних знань, що зберігаються в базах даних про патенти [3, с. 6]. Застосування інформаційно-комунікаційних технологій розглядається як основа сталого розвитку практично всіх елементів соціальної інфраструктури, таких як електронне урядування (е-урядування), електронний уряд (е-уряд), електронна комерційна діяльність (е-комерція), електронне навчання (е-навчання), електронна наукова діяльність (е-наука), електронна охорона здоров'я, електронна зайнятість (е-зайнятість), електронна охорона довкілля, електронне сільське господарство. Інформаційні технології змінюють не види діяльності, а їхню технологічну здатність використовувати як пряму продуктивну силу нові знання [1, с. 3].

Електронне урядування, відповідно до Концепції розвитку електронного урядування в Україні від 20 вересня 2017 р. № 649-р, - це форма організації державного управління, яка сприяє підвищенню ефективності, відкритості та прозорості діяльності органів державної влади та органів місцевого самоврядування з використанням інформаційно-телекомунікаційних технологій для формування нового типу держави, орієнтованої на задоволення потреб громадян [6].

В. Марченко визначено поняття електронного урядування в органах виконавчої влади в широкому та вузькому розумінні. В широкому воно визначено як система взаємовідносин між органами виконавчої влади, фізичними та юридичними особами, іншими органами державної влади, яка будується на дво- чи багатосторонній взаємодії та широкому спектрі інформаційно-комунікаційних технологій, апаратного та програмного забезпечення, достатніх для максимально повного, якісного і своєчасного деперсоналізованого та децентралізованого обслуговування сторін дистанційно в електронній формі чи в режимі реального часу (онлайн) задля задоволення їх потреб і запитів, підвищення ефективності, прозорості та відкритості діяльності органів виконавчої влади. У вузькому воно визначено як специфічна форма й процес організації взаємовідносин між органами виконавчої влади, фізичними та юридичними особами, іншими органами державної влади, який орієнтований на інтерактивне сервісне обслуговування сторін на основі застосування комплексу сучасних інноваційних технічних і технологічних засобів [5, с. 4].

Електронне врядування, як зазначає В. Карачай, покликане зробити публічну адміністрацію більш відкритою та прозорою, заощаджувати 
часові та матеріальні ресурси, підвищувати якість надання адміністративних послуг, забезпечувати доступ до публічної інформації за допомогою сучасних інформаційних технологій, звільняти службовців від рутинної роботи, деперсоніфікувати взаємовідносини громадян, представників бізнесу у взаєминах із державними чиновниками, створити єдиний «пункт взаємодії» громадян із державними структурами, створити можливість цілодобового отримання адміністративних послуг, головне, підвищити рівень демократизації суспільства. Отже, електронне врядування в змозі змінити саму природу влади, зробити iii більш прозорою та підконтрольною громадськості, воно створює сприятливі умови для нормального розвитку бізнесу, покращення інвестиційного клімату, зростання економіки, а також забезпечує реальну участь громадян у політичних процесах, тобто сприяє демократизації суспільства [2, с. 209].

Деякі вчені зазначають, що електронне урядування (електронне урядування) - це форма організації державного управління, яка за рахунок широкого застосування новітніх IKT забезпечує якісно новий рівень відкритої взаємодії держави та суспільства, надання повного комплексу державних послуг для всіх категорій громадян та суб'єктів господарювання. Впровадження електронного урядування передбачає реалізацію послідовного, комплексного та індивідуалізованого підходу до надання державних послуг та інформації для населення. Це означає структурну перебудову функціонування державних органів та їх взаємодіі 3 громадянами, організаціями та власними співробітниками. Впровадження електронного урядування $€$ складним процесом, що вимагає значних фінансових витрат і вирішення цілого комплексу взаємозалежних політичних, правових, адміністративних і технологічних проблем [7, с. 3; 8].

Основними завданнями електронного врядування в соціально-еконо- мічній сфері, на думку I. Клименка, $€$ надання повного спектру інформаційних послуг державними органами всім категоріям громадян електронними засобами в доступній та зручній формі без часових та просторових обмежень; сприяння розвитку електронного ринку товарів та послуг в інтересах забезпечення державних замовлень, організації тендерів, ефективності управління виробництвом та реалізацією товарів і послуг задля зростання конкурентоспроможності вітчизняних виробників на міжнародному ринку; впровадження електронної демократії як форми забезпечення прозорості, довіри у взаємовідносинах між державою й громадянами, приватним бізнесом, громадськими організаціями та інституціями; відкритість державного управління для громадянського та суспільного обговорення, контролю та ініціатив; підвищення якості життя громадян за рахунок удосконалення системи соціальних послуг, системи охорони здоров'я, надійного забезпечення правової та особистої безпеки, збільшення можливостей для освіти, екологічної безпеки; функціонування системи електронного голосування як форми забезпечення прозорості виборчого процесу, зворотного зв'язку взаємовідносин «виборець - депутат» та контролю діяльності депутатів з боку виборців [6, с. 66].

Висновки. Отже, електронне урядування у сфері адміністративно-правового забезпечення патентної діяльності в Україні за своїм змістом $є$ системною, стратегічною та інформаційно-технологічною діяльністю суб'єктів публічної адміністрації патентування, що пов'язана $з$ веденням ними виконавчо-розпорядчої діяльності, що супроводжується використанням інформаційно-комунікаційних технологій та діяльністю щодо надання високоякісних електронно-інформаційних адміністративних послуг у сфері патентної діяльності.

Метою електронного урядування у сфері адміністративно-правового 
забезпечення патентної діяльності в Україні є забезпечення принципів відкритості та прозорості суб'єктів публічної адміністрації, надання високоякісних адміністративних послуг та розвиток системи захисту інтелектуальних прав шляхом впровадження інформаційних технологій у адміністративно-правове забезпечення патентної діяльності.

Актуальність статті полягає в тому, що перетворення інформацүї на найважливіший виробничий ресурс змінюе парадигму еволюиіi суспільства: основу розвитку інформаційного суспільства складають не традиційні матеріальні, а інформаційні, інтелектуальні ресурси, такі як знання, наука, організация, здібності людей, ̈̈хня ініціатива, формування структур і механізмів якісно нового социільного інтелекту, які відкривають кожному співтовариству нові можливості для самоідентифікації, тому для розбудови інформаиійного суспільства в Україні варто більи системно вивчити можливості електронного урядування в окремих секторах правового регулювання, зокрема у сфері адміністративно-правового забезпечення патентної діяльності в Україні. Мета статmі полягає в тому, щоб на основі системного аналізу норм законодавства, позицій учених-адміністративістів та науковців інтелектуального права, статистичної діяльності суб’єктів публічної адміністрації патентної діяльності сформувати зміст електронного урядування у сфері адміністративно-правового забезпечення патентної діяльності в Україні. У статті сформовано зміст електронного урядування у сфері адміністративно-правового забезпечення патентної діяльності в Україні як системної, стратегічної та інформаційно-технологічної діяльності суб'єктів публінної адміністрациї патенту- вання, пов'язаної з веденням ними виконавчо-розпорядчої діяльності, що супроводжується використанням інформаційно-комунікаційних технологій та діяльністю щодо надання високоякісних електронно-інформаційних адміністративних послуг у сфері патентної діяльності. Зроблено висновок, шо метою електронного урядування у сфері адміністративно-правового забезпечення патентної діяльності в Україні є забезпечення принuциів відкритості та прозорості суб'єктів публічної адміністрації, надання високоякісних адміністративних послуг та розвиток системи захисту інтелектуальних прав шляхом впровадження інформаційних технологій в адміністративно-правове забезпечення патентної діяльності.

Ключові слова: адміністративноправове забезпечення, електронне врядування, інструменти, механізм, патент, патентна діяльність, принципи, публічна адміністрація, статус, суб'єКТ.

Kudin A. The content of e-government in the field of administrative and legal support of patent activity in Ukraine

The relevance of the article is that the transformation of information into the most important production resource changes the paradigm of evolution of society is the basis of information society is not traditional material but informational, intellectual resources: knowledge, science, organization, human abilities, their initiative, formation of structures and mechanisms new social intelligence, which opens new opportunities for each community for self-identification. Therefore, in order to develop the information society in Ukraine, it is necessary to more systematically study the possibilities of e-government in certain sectors of legal regulation, in particular, 
in the field of administrative and legal support of patent activity in Ukraine. The purpose of the article is to form the content of e-government in the field of administrative and legal support of patent activity in Ukraine on the basis of a systematic analysis of legislation, positions of scientists-administrators and scholars of intellectual law, statistical activities of public administration of patent activity. The article forms the content of e-government in the field of administrative and legal support of patent activities in Ukraine as a systemic, strategic and information technology activities of public administration of patenting, related to the implementation of executive and administrative activities, accompanied by the use of information and communication technologies and activities to provide high-quality electronic information administrative services in the field of patent activity. It is concluded that the purpose of e-government in the field of administrative and legal support of patent activity in Ukraine is to ensure the principles of openness and transparency of public administration, providing high quality administrative services and development of intellectual property protection through the introduction of information technology in administrative and legal support of patent activity.

Key words: administrative and legal support, e-government, tools, mechanism, patent, patent activity, principles, public administration, status, subject.

\section{Література}

1. Клімушин П., Спасібов Д., Радченко О. Механізми електронного урядування в інформаційному суспільстві : монографія. Харків : вид-во ХарРІ НАДУ «Магістр», 2017. $116 \mathrm{c}$

2. Карачай В. Теоретико-методологічні аспекти проблеми демократизаціі українського суспільства за допомогою електронного врядування. Політологічні записки. 2013. № 2. С. 206-217.

3. Клімушин П. Стратегіi та механізми електронного урядування в інформаційному суспільстві : монографія. Харків : вид-во ХарРІ НАДУ «Магістр», 2016. 524 c.

4. Клименко I. Соціальні аспекти електронного врядування. Економіка та держава. 2009. № 10. С. 64-66.

5. Марченко В. Адміністративно-правові засади електронного урядування в органах виконавчої влади: автореф. дис. ... докт. юрид. наук : спеи. 12.00.07; МBC України, Харківський національний університет внутрішніх справ, 2016. 44 c.

6. Про схвалення Концепції розвитку електронного урядування в Україні : Розпорядження Кабінету Міністрів України від 20 вересня 2017 р. № 649-р / Верховна Рада України. 2017. URL: https:// zakon.rada.gov.ua/laws / show /649-2017$\%$ D1\%80\#Text.

7. СеменченкоА.,БарановО.,ДемковаМ., Дзюба С. Проєкт навчального посібника «Концептуальні засади розвитку електронного урядування в Україні». 2009. 82 с.

8. Слюсаренко В. Електронне врядування як ефективний інструмент трьохстороннього партнерства. Економіка. Фінанси. Право. 2017. № 4 (1). С. 49-52. 